\title{
PHYSIOLOGICAL CHANGES IN SUGARCANE IN FUNCTION OF AIR AND GROUND APPLICATION OF FUNGICIDE FOR ORANGE RUST CONTROL
}

\author{
ALTERAÇÕES FISIOLÓGICAS NA CANA-DE-ACÚCAR EM FUNÇÃO DE \\ APLICAÇÕES AÉREAS E TERRESTRE DE FUNGICIDA NO CONTROLE DA \\ FERRUGEM ALARANJADA
}

\author{
Thales Cassemiro ALVES ${ }^{1}$; João Paulo Arantes Rodrigues da CUNHA ${ }^{2}$; \\ Ernane Miranda LEMES $^{3}$; Renata Leandra de Almeida CASTRO ${ }^{4}$; \\ João Eduardo Ribeiro da SILVA ${ }^{3}$; César Henrique Souza ZANDONADI ${ }^{1}$ \\ 1. Doutorando em Agronomia, Programa de Pós-Graduação em Agronomia, Universidade Federal de Uberlândia, Uberlândia, MG, \\ Brasil; 2. Professor, Universidade Federal de Uberlândia, Uberlândia, MG, Brasil, jpcunha@ufu.br; 3. Doutor em Agronomia, \\ Universidade Federal de Uberlândia, Uberlândia, MG, Brasil; 4. Mestre em Agronomia, Universidade Federal de Uberlândia, \\ Uberlândia, MG, Brasil.
}

\begin{abstract}
The application of fungicides in different operating conditions is a usual practice for maintaining the productive potential in sugarcane varieties considered susceptible to orange rust, however, the physiological effects provided by the different application methods are unknown. The objective of this study was to evaluate the photosynthetic responses (gas exchange and chlorophyll content) in the SP81-3250 sugarcane variety, in function of different operational conditions of the aerial and ground application of fungicide in the orange rust control. Two application of fungicides of the chemical groups Strobilurins and Triazoles were carried out in the experimental units in different treatments. In the aerial applications, two application rates $\left(30\right.$ and $\left.40 \mathrm{~L} \mathrm{ha}^{-1}\right)$ and three nozzle orientations $\left(0^{\circ}, 90^{\circ}\right.$ and $\left.135^{\circ}\right)$ and in the ground application was used $200 \mathrm{~L} \mathrm{ha}^{-1}$ and flat fan spray nozzles with air induction (AI11004-VS). Gas exchange evaluations were performed with an IRGA and amount of chlorophyll $a$ and $b$ with a chlorophyll meter. Data were analyzed using Student's t-test for independent samples, at 0.05 significance. The aerial application provided better photosynthetic responses and chlorophyll $a$ and $b$ contents in leaf limb compared to ground application. Significant differences were detected in gas exchange and chlorophyll content between application rates and angulation of the spray nozzles in the boom. Fungicide applications provided increments of more than $19 \mathrm{t} \mathrm{ha}^{-1}$ compared to the control, depending on the spraying technique employed. Aerial application with $30 \mathrm{~L} \mathrm{ha}^{-1}$ and $0^{\circ}$ of deflection is a viable option to provide safer applications as a function of the larger droplet size.
\end{abstract}

KEYWORDS: Application technology. Leaf gas exchange. IRGA. Saccharum spp. Puccinia kuehnii.

\section{INTRODUCTION}

Sugarcane (Saccharum spp.) stands out as one of the main Brazilian agricultural crops, mainly as a source of energy biomass. On the other hand, the recent finding of sugarcane orange rust (Puccinia kuehnii (W. Krüger) EJ Butler) in the region of Araraquara-SP/Brazil has been worrying producers and technicians for the damages they can cause to the crop (BARBASSO et al., 2010). According to Araújo et al. (2013), in several countries, including Brazil, susceptible varieties (e.g., RB72454, SP89-1115, SP84-2025, SP813250, SP77-5181, CTC 9 and 15) had more than $40 \%$ yield reduction. Zhao et al. (2011) stated that this disease reduces the development and productivity of the crop, to the detriment of a lower content of chlorophyll in the leaves, efficiency in carbon fixation, stomatal conductance, liquid photosynthetic rate and leaf transpiration. It is widespread throughout the state of São Paulo, and present in the main producing regions of Brazil (CHAPOLA, 2013).

The orange rust etiological agent, $P$. kuehnii, is a biotrophic fungus, had low range of hosts and is one of the main threats to the Brazilian sugarcane fields, attacking mainly plants of the generus Saccharum. The orange dust lesions rapidly progressed and ruptured leaves epidermis, forming pale orange pustules, mainly observed on the abaxial face of the leaves, facilitating their identification in the field (GLYNN et al., 2010). The preventive application of fungicides in susceptible varieties, during the favorable periods to the development of the disease, has been shown to be effective, with the maintenance of yield potential (MARGAREY, 2008).

Strobilurin compounds act by inhibiting the mitochondrial respiration of the fungal cells, thus blocking electron transfer between cytochrome $b$ and $c_{1}$ at the $\mathrm{Q}_{0}$ site, affecting the production of ATP (OLIVEIRA, 2016). These compounds act as a preventive inhibitor of spore germination, 
presenting a curative and eradicating action, preventing the development of fungi in the initial and post-germination stages (RODRIGUES, 2006).

Researches have shown that some fungicides, especially the strobilurin group, can also promote physiological changes in the plant, such as increase in chlorophyll content, nitrogen assimilation and photosynthetic rate. In addition, they can help directly in the development of higher biotic and abiotic stresses tolerance, due to its action on the metabolism of abscisic acid and antioxidant enzymes, which would consequently increase productivity (RODRIGUES, 2009; JULIATTI et al., 2012; CARRIJO, 2014).

Studies with various crops such as soybeans, wheat and beans report the effect of strobilurins on plant physiology (RODRIGUES et al., 2009; LENZ et al., 2011; DEMANT; MARINGONI, 2012). However, few studies about the effect of strobilurins on sugarcane cultivation were done, with regard to the increase of photosynthetic activity, gas exchange, chlorophyll content and increase in yield. In addition, there are several reports in the literature on inefficient crop spraying of phytosanitary products, by either excess or lack of active ingredient in biological targets. It is essential that application techniques provide the correct deposit of droplets generated during spraying on biological targets and it is necessary a better understanding of spraying equipment and the plant architecture in order to obtain maximum efficiency, avoiding the contamination of adjacent areas (VAN ZYL et al., 2013; ALVES; CUNHA, 2014).

Thus, this study aimed to evaluate the photosynthetic responses, chlorophyll $a$ and $b$ content, biometric variables and the SP81-3250 yield, using different operational conditions in the aerial and ground applications of fungicides in the management of sugarcane orange rust.

\section{MATERIAL AND METHODS}

The field study was carried out in commercial areas cultivated with SP81-3250 sugarcane variety, belonging to the Company of Sugar and Alcohol of Minas Gerais (CMAA) located in Uberaba, MG, Brazil. The climate in the region is classified by Köppen (1948), as Aw, which is tropical wet and dry season during the winter. The farm is located at $19^{\circ} 24^{\prime} 45^{\prime \prime} \mathrm{S}$ and 48 $9^{\prime} 46^{\prime \prime} \mathrm{W}$ geographic coordinates and $803 \mathrm{~m}$ above mean sea level. The crop was planted on July $30^{\text {th }}, 2011$, spaced $1.5 \mathrm{~m}$ between rows and adapted to mechanical harvesting. During the applications, the crop was in its fourth-year sugarcane ratoon.

\section{Fungicide application details}

The fungicide applications were defined through inspections in the field, especially when the weather conditions were favorable for the disease development. Two applications were carried out, with the sugarcane plants at the phenological stage of tillering (first application) and crop establishment (second application), according to Gascho and Shih (1983).

The first and second applications of fungicides were performed on January $29^{\text {th }}$ and March $23^{\text {rd }}, 2015$, respectively, due to high natural infection of sugarcane orange rust. This second application follows the same methodology as the first application performed in January. Before the sugarcane was harvested on October 12th, 2015, was not necessary a third application of fungicide for the sugarcane completed its cycle.

In the first application, the systemic fungicide Approach ${ }^{\circledR}$ Prima (DuPont do Brasil S.A., Barueri, SP) was used at $0.4 \mathrm{~L} \mathrm{ha}^{-1}(80 \mathrm{~g}$ picoxystrobin $\mathrm{ha}^{-1}+32 \mathrm{~g}$ cyproconazole $\mathrm{ha}^{-1}$ ) plus $0.5 \mathrm{~L} \mathrm{ha}^{-1}$ of mineral oil (Nimbus ${ }^{\circledR}$, Syngenta, Paulínia, SP). In the second application, another systemic fungicide Opera ${ }^{\circledR}$ (BASF, São Paulo, SP) was used at $1.0 \mathrm{~L} \mathrm{ha}^{-1}$ (133 $\mathrm{g}_{\text {pyraclostrobin } \mathrm{ha}^{-1}+}+$ $50 \mathrm{~g}$ epoxiconazole ha ${ }^{-1}$ ) plus $0.5 \mathrm{~L} \mathrm{ha}^{-1}$ of mineral oil (Assist ${ }^{\circledR}$, BASF, São Paulo, SP).

All fungicides treatments were detailed in Table 1. For aerial fungicide applications, two application rates (30 and $\left.40 \mathrm{~L} \mathrm{ha}^{-1}\right)$ and three deflection angles of the nozzles were used at the spray boom. The angles were in relation to the flight line: $0^{\circ}$ (parallel and straight back), $90^{\circ}$ (perpendicular and up down) and $135^{\circ}$ (forward into the wind), for droplets initially considered as coarse, medium and fine droplets, respectively. Applications performed at $90^{\circ}$ deflection angle were considered as standard by the applicators and were evaluated only in the second application.

For ground application, $200 \mathrm{~L} \mathrm{ha}^{-1}$ sprayed through flat fan spray nozzles with air induction, producing extremely coarse droplets. This treatment was considered the most used by the company and evaluated only in the first application because the sugarcane was $1.5 \mathrm{~m}$ height, which did not allow the use of ground sprayers in the second application.

Treatment 5, regarded as the sugar mill standard, first received the ground application and then an aerial application in a new experimental area. The other treatments were similar in both applications. Additionally there was one treatment 
that did not received application of fungicide (control).

Table 1. Description of the treatments used in the application of fungicides on sugarcane.

\begin{tabular}{llllll}
\hline Treatment & Application method & $\begin{array}{l}\text { Application rate } \\
\left(\mathrm{L} \mathrm{ha}^{-1}\right)\end{array}$ & $\begin{array}{l}\text { Application speed } \\
\left(\mathrm{km} \mathrm{h}^{-1}\right)\end{array}$ & $\begin{array}{l}\text { Nozzle } \\
\text { orientation }\end{array}$ & $\begin{array}{l}\text { Work } \\
\text { pressure } \\
(\mathrm{kPa})\end{array}$ \\
\hline 1 & Aerial & 30 & 168 & $135^{\mathbf{0}}$ & 207 \\
2 & Aerial & 30 & 168 & $0^{\circ}$ & 207 \\
3 & Aerial & 40 & 168 & $0^{\circ}$ & 276 \\
4 & Aerial & 40 & 168 & $135^{\circ}$ & 276 \\
5 & Ground (Standard) & 200 & 7 & --- & 207 \\
6 & Aerial (Standard) & 30 & 168 & $90^{\circ}$ & 207 \\
\hline
\end{tabular}

In ground applications, coupled to the hydraulic system of a tractor, Falcon hydraulic sprayer was used (Jacto S/A, Pompéia, SP, Brazil) with $14 \mathrm{~m}$ width boom, $800 \mathrm{~L}$ tank capacity and electronic spray controller was used. The nozzles used were AI 11004-VS (Spraying Systems Co., Wellaton, IL, USA) spaced $0.5 \mathrm{~m}$ between each other and positioned $0.4 \mathrm{~m}$ above the canopy. The application was performed at $7 \mathrm{~km} \mathrm{~h}^{-1}$ and $207 \mathrm{kPa}$ of pressure.

In aerial applications, an agricultural aircraft EMBRAER, EMB 202A (Embraer, Botucatu, SP, Brazil) had its spray boom equipped with 43 hollow cone nozzles disc \#8 and core \#45 (Spraying Systems Co., Wellaton, IL, USA). The flight speed and flight height were at $168 \mathrm{~km} \mathrm{~h}^{-1}(105 \mathrm{mph})$ and $3 \mathrm{~m}$ above the canopy, respectively. The pressures during the applications were kept at $207 \mathrm{kPa}$ for 30 $\mathrm{L} \mathrm{ha}^{-1}$ and $276 \mathrm{kPa}$ for $40 \mathrm{~L} \mathrm{ha}^{-1}$.

Experimental plots were sized $100 \mathrm{~m}$ length x $48 \mathrm{~m}$ width for aerial applications and $100 \mathrm{~m}$ length $\times 7 \mathrm{~m}$ width for ground applications, whose width corresponded to three crosswind passes by aircraft and half-boom section of ground sprayer, respectively. The plots that did not receive application of fungicides sized $100 \mathrm{~m}$ length $\mathrm{x} 9 \mathrm{~m}$ width. The samples were collected in the central area of each plot, sizing $90 \times 16 \mathrm{~m}, 90 \times 5.0 \mathrm{~m}$ and $90 \times 7.0 \mathrm{~m}$ for aerial, ground and none application, respectively. The difference among plot dimensions was due to application methods and area format.

The environmental conditions of temperature $\left({ }^{\circ} \mathrm{C}\right)$, relative air humidity $(\%)$ and wind speed $\left(\mathrm{km} \mathrm{h}^{-1}\right)$ were recorded during the applications using a portable weather station (Kestrel $\left.{ }^{\circledR}, 4000\right)$. The conditions vary between 28 and $30^{\circ} \mathrm{C}, 50$ and $57 \%$ and 4 and $6 \mathrm{~km} \mathrm{~h}^{-1}$, respectively.

\section{Evaluation of gas exchange and chlorophyll $a$ and $b$ content}

Evaluations of gas exchange and chlorophyll a and $\mathrm{b}$ contents were held respectively, with an Infrared Gas Analyzer - IRGA - (LCpro-SD model, ADC BioScientific Ltda.) and a chlorophyll meter (ClorofiLOG CFL-1030, from Falker Agricultural Automation). These evaluations occurred after the first application of the fungicide, on February $3^{\text {rd }}, 10^{\text {th }}$ and $23^{\text {rd }}, 2015$; and after the second application, on March 31 and April 7 and 18, 2015.

For the gas exchange evaluations an artificial light gun was used on the chamber so that, during the measurements, all the leaves received $1200 \mu \mathrm{mol} \mathrm{m}{ }^{-2}$ of photon flux density. For each leaf analyzed, the equipment was stabilized and, after about one minute, three consecutive readings were collected in seven plants per treatment, totalizing 21 samplings. The same evaluator was used to reduce the sampling error when taking the readings. The evaluations were conducted with sky without cloud, between 8 am and 10 am, so there were no extremes of temperature. In each plant in the upper canopy was sampled the pointer leaf and in the middle third, the first fully expanded leaf and the apparent leaflet (leaf ' +1 ') (SALES et al., 2012; ARANTES et al., 2013).

The ratios of instantaneous water use efficiency $(W / E)$, intrinsic water use efficiency $(\mathrm{W} / \mathrm{gs})$ and carboxylation efficiency $(\mathrm{A} / \mathrm{Ci})$ were calculated from IRGA data. These data demonstrate the photosynthetic performance of a plant, allowing a better evaluation of the gas exchange and the physiology of this plant.

The chlorophyll $a$ and $b$ content, represented by ICF (Falker chlorophyll index) were evaluated with the chlorophyll meter. The readings were made randomly, in seven plants at each 
treatment. For chlorophyll assessment, ChlorofiLOG uses two emitters at wavelengths close to the peaks of each type of chlorophyll $(\lambda=$ 635 and $660 \mathrm{~nm}$ ) and one emitter at near infrared wavelengths $(\lambda=880 \mathrm{~nm})$.

\section{Sugarcane yield}

The biometric assessments of sugarcane were carried out on October 12, 2015, three days before the beginning of the sugar cane harvest in the areas (sugar cane with 12 months, 4th year of sugarcane ratoon), according to the method proposed by Martins and Landell (1995):

The number of stems per linear meter was estimated by counting 30 points in the useful area in order to determine the stand, counting only the stems favorable to industrialization. To determine the stems length, the heights of 30 industrialized stems were measured in the useful area, between the cut - off point and the breaking point of the stem. A scale for the height measurements was used. The stem diameters were measured, in the useful area, using a pachymeter, considering the lower thirds of 30 industrializable stems. For the stems mass, 30 industrializable stems were sampled, in the useful area, with the aid of a portable digital scale.

From this data, and considering the stem density equal to 1 , it was possible to estimate the productivity, expressed in tons of cane per hectare $(\mathrm{TCH})$, using the following mathematical expression: $\mathrm{TCH}=\mathrm{D}^{2} \times \mathrm{S} \times \mathrm{L} \times(0.007854 / \mathrm{Fs})$ where; $\mathrm{D}=$ stem diameter $(\mathrm{cm}) ; \mathrm{S}=$ number of stems per linear meter; $\mathrm{L}=$ stem length $(\mathrm{cm})$ and $\mathrm{Fs}$ = furrow spacing $(\mathrm{m})$.

\section{Statistical analysis}

The results of both application dates were independently considered and evaluated separately, first submitted to presupposition analysis, tested by the Kolmogorov-Smirnov (KS) and Levene tests to analyze the residues normality and the homogeneity of the variances, respectively, at $\alpha=0.01$. The data were then analyzed using Student's t-test for independent samples at $\alpha=0.05$, using the SPSS Statistical Software, Version 17.0 (SPSS Inc., Chicago, IL, USA).

\section{RESULTS AND DISCUSSION}

Among the physiological parameters, the transpiration rate $\left(E, \mathrm{mmol} \mathrm{m} \mathrm{m}^{-2} \mathrm{~s}^{-1} \mathrm{H}_{2} \mathrm{O}\right)$ and the carbon assimilation rate $\left(A, \mu \mathrm{mol} \mathrm{m} \mathrm{s}^{-2} \mathrm{CO}_{2}\right)$ by the leaves of the SP81-3250 were the most expressive in terms of momentary photosynthetic efficiency evaluation.
The application of fungicides provided a momentary efficiency of the gas exchanges compared to the untreated areas. There was no difference in this efficiency and carbon assimilation rates, in relation to the techniques used in the spraying, in the last evaluation of the first application (Table 2). In the second application of fungicide, the rates of transpiration and carbon assimilation did not differ with the application technologies, mainly in the first evaluations.

Transpiration rate $(E)$ and carbon assimilation $(A)$ were generally higher when aerial application was used in the different forms of spraying, especially in the first application. The use of fine droplets should be primarily considered in aerial applications to provide satisfactory coverage and uniform spray distribution. However, small droplets exposed to unfavorable climatic conditions, such as low relative humidity, high temperatures and wind speeds, are more likely to be evaporated and lost by drift (VILLALBA; HETZ, 2010). Czaczyk et al. (2012) reported that thicker droplets can jump, break and slip through the leaves and reach other targets. However, areas that were treated with an application rate of $30 \mathrm{~L} \mathrm{ha}^{-1}$ in the angle orientation of the spray nozzle at $135^{\circ}$ of deflection generally produced better results of momentary efficiency of gas exchanges.

Changes in plant gas exchange physiological parameters after application of phytosanitary products are effects already reported in the literature (TORRES et al., 2012; CARRIJO, 2014; ZANDONADI et al., 2017). Besides the thermal effect that fungicide solutions can induce on treated leaves, Biggs (1990) has already pointed out that the application of triazole fungicides could induce changes in leaf transpiration and that these effects would persist for several days after application. These changes observed in the foliar transpiration rate in fungicide treatments with Triazoles were justified by changes in potassium $\left(\mathrm{K}^{+}\right)$concentration in the stomata guard cells, which made them turgid, allowing the stomata opening (Taiz; Zeiger, 2013).

Similar to the present results, the rate of carbon assimilation $(A)$, or photosynthesis rate, was also higher for treatments containing Triazoles (tebuconazole) and Strobilurin (pyraclostrobin) in soybean crop treated with fungicides at the reproductive stage, with persistent results until the $17^{\text {th }}$ day after the application of the fungicides (FAGAN et al., 2010). According to Martins (2011), the mixtures of Strobilurin + Triazole (pyraclostrobin + apoxiconazole) increase soybean 
transpiration rate more than the pure triazole fungicide.

Table 2. Physiological evaluations of the momentary efficiency of the transpiration rate and carbon assimilation rate after the first and second aerial and ground applications of fungicides in the SP813250 sugarcane variety for the management of orange rust.

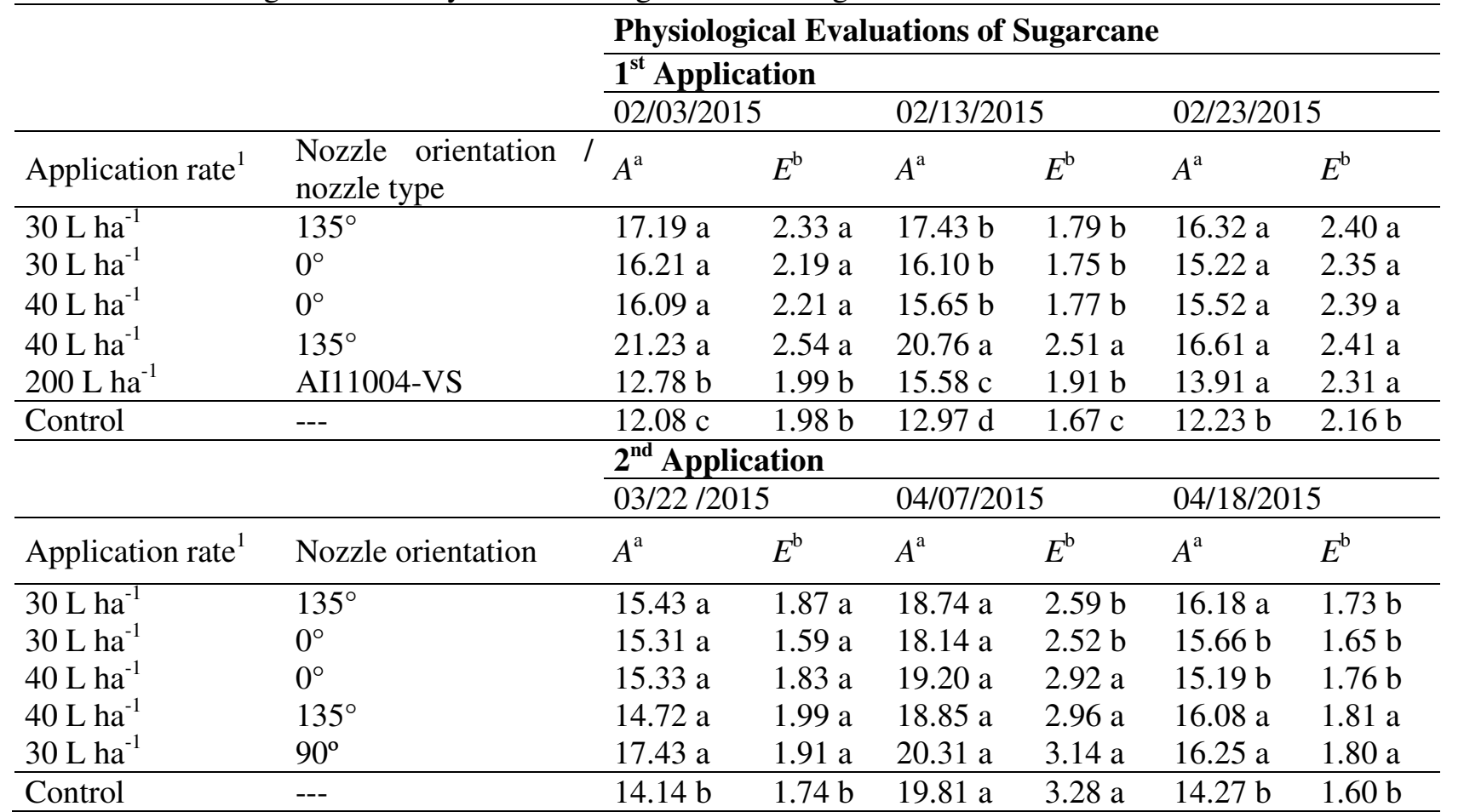

${ }^{\mathrm{T}}$ Means followed by distinct letters in the column differ from each other by Student's t-test, 0.05 significance. $\mathbf{a}$ : carbon assimilation rate $\left(A, \mu \mathrm{mol} \mathrm{m} \mathrm{m}^{-2} \mathrm{sO}_{2}\right)$; b: transpiration rate $\left(E, \mathrm{mmol} \mathrm{m}^{-2} \mathrm{~s}^{-1} \mathrm{H}_{2} \mathrm{O}\right)$.

In sugarcane, the highest carbon assimilation rate persisted until the second evaluation, 15 days after the application, which is understandable because of the fine droplets, mainly in aerial applications that provide a satisfactory coverage and uniform distribution of the first application. The responses of carbon assimilation were equivalent to those of the transpiration rate, that is, where greater transpiration occurred; there was also greater carbon assimilation, since both variables are directly dependent on the stomatal opening. In other words, if there is high transpiration it is because the stomata are open and naturally higher amounts of $\mathrm{CO}_{2}$ can enter in the leaf and be converted to assimilated carbon, which will ultimately increase the final biomass production.

In relation to the instantaneous water use efficiency $(W / E)$, when the aerial application was used at the different application rates and in the different orientations of the nozzle angles, the averages were higher than those of the ground application (Table 3), differing from both the ground application as the control plant, in the first application. In the second application, it was observed that the averages were higher, when the application rate of $30 \mathrm{~L} \mathrm{ha}^{-1}$ was used in comparison with the $40 \mathrm{~L} \mathrm{ha}^{-1}$ rate. This behavior may also be a reflection of the difference in fungal syrup deposition applied to the culture.

The instantaneous water use efficiency is characterized as the amount of water transpired by a crop to produce a certain amount of dry matter (SILVA; SILVA, 2007). Thus, when crops were more efficient in the use of water, they can produce higher amount of dry matter per gram of transpired water. The most efficient use of water is directly related to the stomatal opening time, because, while the plant absorbs $\mathrm{CO}_{2}$ for photosynthesis, the water is lost by transpiration with variable intensity depending on the potential gradient between the leaf surface and the atmosphere, followed by a current of water potentials (CONCENÇO et al., 2007). The instantaneous efficiency of water use $(W / E)$ is therefore a ratio between the net photosynthesis rate and the leaf transpiration rate at the time of evaluation, and any management or stress that reduces carbon assimilation, or photosynthetic rate, and/or increase the transpiration rate will negatively affect the instantaneous efficiency of water use. 
Table 3. Physiological evaluations of the instant efficiency of water use (W/E) after the first and second aerial and ground applications of fungicides in the SP81-3250 sugarcane variety for the management of orange rust.

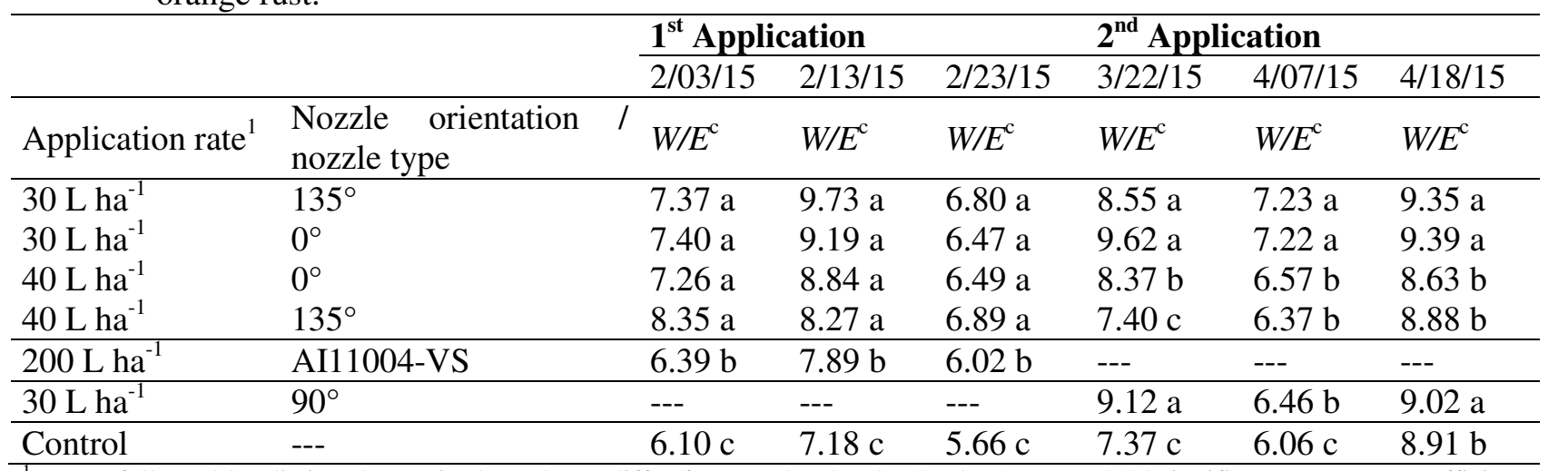

${ }^{\mathrm{l}}$ Means followed by distinct letters in the column differ from each other by Student's t-test, 0.05 significance. c: Instant efficiency of water use $\left(W / E, 0,001 \mathrm{mmol} \mathrm{CO}_{2}\left(\mathrm{mmol} \mathrm{H}_{2} \mathrm{O}\right)\right)$.

Another photosynthetic parameter is the ratio $\mathrm{W} / \mathrm{gs}$, or intrinsic water use efficiency, which expresses the amount of carbon that is assimilated via photosynthesis per unit of evaporated water via stomata (BELLOTI, 2012). In relation to this measure, when the aerial application was used in the different spraying techniques, the averages were higher than those of the ground application (Table 4), especially in the first evaluation of the first application. However, the differences were not significant between the rates of application and the orientation of the nozzle angles. In the third evaluation of the first application, this differentiation was no longer visible. In the second application, it was observed that, in general, the application rate of $30 \mathrm{~L} \mathrm{ha}^{-1}$ presented higher averages compared to the $40 \mathrm{~L} \mathrm{ha}^{-1}$ rate, with emphasis on the orientation of the nozzle angle in $135^{\circ}$ and $0^{\circ}$ in which presented higher means in the three evaluations.

Table 4. Intrinsic efficiency of water use (w/gs) in leaf ' +1 ' of sugarcane after the first and second aerial and ground applications of fungicides in the SP81-3250 sugarcane variety for the management of orange rust.

\begin{tabular}{|c|c|c|c|c|c|c|c|}
\hline & & $1^{\text {st }}$ Appl & ion & & $2^{\text {nd }}$ Apl & ation & \\
\hline & & $2 / 03 / 15$ & $2 / 13 / 15$ & $2 / 23 / 15$ & $3 / 22 / 15$ & $4 / 07 / 15$ & $4 / 18 / 15$ \\
\hline $\begin{array}{l}\text { Application } \\
\text { rate }^{1}\end{array}$ & $\begin{array}{l}\text { Nozzle orientation } \\
\text { nozzle type }\end{array}$ & $W / g s^{\mathrm{d}}$ & $W / g s^{\mathrm{d}}$ & $W / g s^{\mathrm{d}}$ & $W / g s^{\mathrm{d}}$ & $W / g s^{\mathrm{d}}$ & $W / g s^{\mathrm{d}}$ \\
\hline $30 \mathrm{~L} \mathrm{ha}^{-1}$ & $135^{\circ}$ & $177.2 \mathrm{a}$ & $169.8 \mathrm{~b}$ & $155.2 \mathrm{a}$ & $154.9 \mathrm{a}$ & $151.6 \mathrm{a}$ & $155.2 \mathrm{a}$ \\
\hline $30 \mathrm{~L} \mathrm{ha}^{-1}$ & $0^{\circ}$ & $170.4 \mathrm{a}$ & $171.8 \mathrm{a}$ & $148.6 \mathrm{a}$ & $154.2 \mathrm{a}$ & $152.9 \mathrm{a}$ & $148.6 \mathrm{a}$ \\
\hline $40 \mathrm{~L} \mathrm{ha}^{-1}$ & $0^{\circ}$ & $170.3 \mathrm{a}$ & $181.3 \mathrm{a}$ & $158.6 \mathrm{a}$ & $165.7 \mathrm{a}$ & $140.4 \mathrm{~b}$ & $136.4 \mathrm{~b}$ \\
\hline $40 \mathrm{~L} \mathrm{ha}^{-1}$ & $135^{\circ}$ & $168.8 \mathrm{a}$ & $159.2 \mathrm{c}$ & $145.1 \mathrm{a}$ & $157.2 \mathrm{a}$ & $139.9 \mathrm{~b}$ & $130.1 \mathrm{~b}$ \\
\hline $200 \mathrm{~L} \mathrm{ha}^{-1}$ & AI11004-VS & $153.2 \mathrm{~b}$ & $160.2 \mathrm{c}$ & $151.4 \mathrm{a}$ & --- & --- & --- \\
\hline $30 \mathrm{~L} \mathrm{ha}^{-1}$ & $90^{\circ}$ & --- & --- & --- & $161.9 \mathrm{a}$ & $134.9 \mathrm{~b}$ & $158.6 \mathrm{a}$ \\
\hline Control & --- & $143.3 \mathrm{c}$ & $159.7 \mathrm{c}$ & $149.5 \mathrm{a}$ & $134.1 \mathrm{~b}$ & $135.0 \mathrm{~b}$ & $111.5 \mathrm{c}$ \\
\hline
\end{tabular}

${ }^{1}$ Means followed by distinct letters in the column differ from each other by Student's t-test, 0.05 significance. d: Intrinsic efficiency of water use $\left(W / g s, 0,001 \mathrm{mmol} \mathrm{CO}_{2}\left(\mathrm{mmol} \mathrm{H}_{2} \mathrm{O}\right)\right)$.

Strobirulins physiological effects in plants are related to their fungitoxic action, which in some way interferes partially with the respiration of the plant cell, consequently affecting the liquid photosynthesis of the plant, including potentiating the carbon and nitrogen assimilation, as well as considerably increasing nitrate reductase proteins activity (KÖHLE et al., 2002; RODRIGUES, 2009).

As the plant gas exchange with the atmosphere is regulated by the stomata, the absorption of $\mathrm{CO}_{2}$ also promotes the loss of $\mathrm{H}_{2} \mathrm{O}$. The decrease of this loss consequently restricts the entry of $\mathrm{CO}_{2}$ (SHIMAZAKI et al., 2007). Therefore, in order for the plants to have a higher efficiency of water use, it is necessary to absorb the maximum $\mathrm{CO}_{2}$ with the least possible loss of $\mathrm{H}_{2} \mathrm{O}$ (TAIZ; ZEIGER, 2013). However, as presented by Blum (2005), genotypic differences in the intrinsic efficiency of water use $(\mathrm{W} / \mathrm{gs})$ are expressed when variations occur in plant water use, or in stomatal 
conductance $(g s)$. As carbon assimilation $(A)$ has a direct correlation with stomatal conductance, it is common to increase $\mathrm{A} / \mathrm{gs}$ to result in lower biomass production and reduced yields.

Regarding the instantaneous carboxylation efficiency $(A / C i)$, the averages were higher using aerial application at different rates of application and orientation of the nozzle angles, with no difference between the first and second evaluations, from the first Application (Table 5). Finally, for the same variable, in the third evaluation after the first application, there was no significant difference between the results of the spray forms and the control.
ALVES, T. C. et al

In both evaluations, in the first application, the result of the ground treatment did not differ from the control, however, in the first two evaluations the aerial sprays were higher to ground. In the second application, it was again shown that the application rate of $30 \mathrm{~L} \mathrm{ha}^{-1}$ provided higher averages in comparison to the $40 \mathrm{~L} \mathrm{ha}^{-1}$ rate; however in the second evaluation it was not possible to verify this difference between the different forms of spraying. This behavior may be a reflection of the satisfactory coverage and uniform distribution of spray in the crop canopy.

Table 5. Rubisco Carboxylation Efficiency (A/ci) in leaf ' +1 ' of sugarcane after the first and second aerial and ground applications of fungicides in the SP81-3250 sugarcane variety for the management of orange rust.

\begin{tabular}{|c|c|c|c|c|c|c|c|}
\hline & \multicolumn{3}{|c|}{$\mathbf{1}^{\text {st }}$ Application } & \multicolumn{3}{|c|}{$2^{\text {nd }}$ Application } \\
\hline & & $2 / 03 / 15$ & $2 / 13 / 15$ & $2 / 23 / 15$ & $3 / 23 / 15$ & $4 / 07 / 15$ & $4 / 18 / 15$ \\
\hline $\begin{array}{l}\text { Application } \\
\text { rate }^{1}\end{array}$ & $\begin{array}{l}\text { Nozzle orientation } \\
\text { nozzle type }\end{array}$ & $A / c i^{\mathrm{e}}$ & $A / c i^{e}$ & $A / c i^{e}$ & $A / c i^{i}$ & $A / c i^{i}$ & $A / c i^{\mathrm{e}}$ \\
\hline $30 \mathrm{~L} \mathrm{ha}^{-1}$ & $135^{\circ}$ & $0.44 \mathrm{a}$ & $0.46 \mathrm{a}$ & $0.63 \mathrm{a}$ & $0.16 \mathrm{~b}$ & $0.25 \mathrm{a}$ & $0.12 \mathrm{a}$ \\
\hline $30 \mathrm{~L} \mathrm{ha}^{-1}$ & $0^{\circ}$ & $0.43 \mathrm{a}$ & $0.34 \mathrm{a}$ & $0.43 \mathrm{a}$ & $0.14 \mathrm{~b}$ & $0.29 \mathrm{a}$ & $0.12 \mathrm{a}$ \\
\hline $40 \mathrm{~L} \mathrm{ha}^{-1}$ & $0^{\circ}$ & $0.30 \mathrm{a}$ & $0.35 \mathrm{a}$ & $0.30 \mathrm{a}$ & $0.25 \mathrm{a}$ & $0.25 \mathrm{a}$ & $0.11 \mathrm{~b}$ \\
\hline $40 \mathrm{~L} \mathrm{ha}^{-1}$ & $135^{\circ}$ & $0.41 \mathrm{a}$ & $0.45 \mathrm{a}$ & $0.49 \mathrm{a}$ & $0.19 \mathrm{a}$ & $0.25 \mathrm{a}$ & $0.11 \mathrm{~b}$ \\
\hline $200 \mathrm{~L} \mathrm{ha}^{-1}$ & AI11004-VS & $0.19 \mathrm{~b}$ & $0.19 \mathrm{~b}$ & $0.02 \mathrm{a}$ & --- & --- & --- \\
\hline $30 \mathrm{~L} \mathrm{ha}^{-1}$ & $90^{\circ}$ & --- & $\begin{array}{ll}-- \\
--\end{array}$ & --- & $0.25 \mathrm{a}$ & $0.24 \mathrm{a}$ & $0.22 \mathrm{a}$ \\
\hline Control & --- & $0.18 \mathrm{~b}$ & $0.21 \mathrm{~b}$ & $0.02 \mathrm{a}$ & $0.16 \mathrm{~b}$ & $0.23 \mathrm{~b}$ & $0.09 \mathrm{c}$ \\
\hline
\end{tabular}

${ }^{1}$ Means followed by distinct letters in the column differ from each other by Student's t-test, 0.05 significance. e: Rubisco Carboxylation Efficiency $\left(A / c i, \mu \mathrm{mol} \mathrm{m} \mathrm{m}^{-2} \mathrm{~s}^{-1} \mathrm{~Pa}^{-1}\right)$.

The negative reaction of some treatments, in which no difference was observed with the control, is probably a consequence of poor management of the stomatal opening, the activity and/or affinity of the Rubisco enzyme by $\mathrm{CO}_{2}$, as discussed by Nason et al. (2007). IRGA results reflect a momentary condition on the sugarcane physiology in the two localities, and although two applications of fungicide are a routine in susceptible varieties, their effects do not always last until the end of the cycle transforming into higher yields.

In relation to the chlorophyll $a$ and $b$ contents, the best values were obtained when using the aerial application in comparison to the ground application (Table 6). However, there was no difference for chlorophyll $b$ in the second evaluation and for both chlorophylls in the third evaluation, from the first application. In the second application, there was no difference in the first two evaluations for the chlorophyll $a$ and $b$ content, as well as the different spraying techniques. The application rate of $30 \mathrm{~L} \mathrm{ha}^{-1}$ in $0^{\circ}$ of deflection orientation was highlighted, providing the best means in the three evaluations.

According to Rambo et al. (2004), the chlorophyll content is a very important parameter for the evaluation of the development of the plant, being used to differentiate the plants with $\mathrm{N}$ deficiency of those that present adequate levels of this element. The use of the chlorophyll meter for this evaluation is adequate because it is a low-cost method, provides results faster than laboratory tests and does not imply destruction of the leaves (ARGENTA et al., 2004).

The application of phytosanitary products, in particular fungicides, provided heavier sugarcane stems compared to untreated stems, although the weights were similar in relation to the techniques used in the spraying (Table 7). However, areas treated with $30 \mathrm{~L} \mathrm{ha}^{-1}$ in the orientation at $0^{\circ}$ and $135^{\circ}$ of deflection, produced higher number of stems per linear meter (11.07 and 11.10), stem diameter $(2.27$ and $2.53 \mathrm{~cm})$, stem length $(200.30$ and $209.37 \mathrm{~cm}$ ), and consequently higher yields (70.83 and $\left.77.88 \mathrm{tha}^{-1}\right)$, respectively. 
Table 6. Evaluation of chlorophyll $a$ and $b$, in leaf ' +1 ' of sugarcane after the first and second aerial and ground applications of fungicides in the SP81-3250 sugarcane variety for the management of orange rust.

\begin{tabular}{|c|c|c|c|c|c|c|c|}
\hline & & \multicolumn{6}{|c|}{$1^{\text {st }}$ Application } \\
\hline & & \multicolumn{2}{|c|}{$02 / 03 / 2015$} & \multicolumn{2}{|c|}{$02 / 13 / 2015$} & \multicolumn{2}{|c|}{$02 / 23 / 2015$} \\
\hline $\begin{array}{l}\text { Application } \\
\text { rate }^{1}\end{array}$ & $\begin{array}{l}\text { Nozzle orientation } \\
\text { nozzle type }\end{array}$ & Chlorop $a^{\mathrm{f}}$ & $\begin{array}{l}\text { Chlorop } \\
b^{\mathrm{f}}\end{array}$ & $\begin{array}{l}\text { Chlorop } \\
a^{\mathrm{f}}\end{array}$ & $\begin{array}{l}\text { Chlorop } \\
b^{\text {f }}\end{array}$ & $\begin{array}{l}\text { Chlorop } \\
a^{\mathrm{f}}\end{array}$ & $\begin{array}{l}\text { Chloro } \\
\mathrm{p} b^{\mathrm{f}}\end{array}$ \\
\hline $30 \mathrm{~L} \mathrm{ha}^{-1}$ & $135^{\circ}$ & $29.97 \mathrm{a}$ & $8.48 \mathrm{a}$ & $27.50 \mathrm{a}$ & $6.28 \mathrm{a}$ & $12.66 \mathrm{a}$ & $5.88 \mathrm{a}$ \\
\hline $30 \mathrm{~L} \mathrm{ha}^{-1}$ & $0^{\circ}$ & $29.80 \mathrm{a}$ & $7.74 \mathrm{a}$ & $27.94 \mathrm{a}$ & $6.90 \mathrm{a}$ & $12.84 \mathrm{a}$ & $7.14 \mathrm{a}$ \\
\hline $40 \mathrm{~L} \mathrm{ha}^{-1}$ & $0^{\circ}$ & $27.64 \mathrm{a}$ & $7.27 \mathrm{a}$ & $26.61 \mathrm{a}$ & $6.98 \mathrm{a}$ & $13.27 \mathrm{a}$ & $6.60 \mathrm{a}$ \\
\hline $40 \mathrm{~L} \mathrm{ha}^{-1}$ & $135^{\circ}$ & $28.99 \mathrm{a}$ & $7.47 \mathrm{a}$ & $27.81 \mathrm{a}$ & $6.60 \mathrm{a}$ & $11.01 \mathrm{a}$ & $8.35 \mathrm{a}$ \\
\hline $200 \mathrm{~L} \mathrm{ha}^{-1}$ & AI11004-VS & $24.75 \mathrm{~b}$ & $6.32 \mathrm{~b}$ & $24.75 \mathrm{~b}$ & $6.28 \mathrm{a}$ & $12.71 \mathrm{a}$ & $4.85 \mathrm{a}$ \\
\hline Control & --- & $21.64 \mathrm{c}$ & $5.32 \mathrm{~b}$ & $22.31 \mathrm{~b}$ & $5.61 \mathrm{a}$ & $13.22 \mathrm{a}$ & $6.48 \mathrm{a}$ \\
\hline \multicolumn{8}{|c|}{ 2nd Application } \\
\hline & & \multicolumn{2}{|c|}{$03 / 22 / 2015$} & \multicolumn{2}{|c|}{$04 / 07 / 2015$} & \multicolumn{2}{|c|}{$04 / 18 / 2015$} \\
\hline $\begin{array}{l}\text { Application } \\
\text { rate }^{1}\end{array}$ & Nozzle orientation & $\begin{array}{l}\text { Chlorop } \\
a^{\mathrm{f}}\end{array}$ & $\begin{array}{l}\text { Chlorop } \\
b^{\mathrm{f}}\end{array}$ & $\begin{array}{l}\text { Chlorop } \\
a^{\mathrm{f}}\end{array}$ & $\begin{array}{l}\text { Chlorop } \\
b^{\text {f }}\end{array}$ & $\begin{array}{l}\text { Chlorop } \\
a^{\mathrm{f}}\end{array}$ & $\begin{array}{l}\text { Chloro } \\
\mathrm{p} b^{\mathrm{f}}\end{array}$ \\
\hline $30 \mathrm{~L} \mathrm{ha}^{-1}$ & $135^{\circ}$ & $23.16 \mathrm{a}$ & $6.28 \mathrm{a}$ & $24.00 \mathrm{a}$ & $5.47 \mathrm{a}$ & $22.41 \mathrm{~b}$ & $5.61 \mathrm{~b}$ \\
\hline $30 \mathrm{~L} \mathrm{ha}^{-1}$ & $0^{\circ}$ & $24.47 \mathrm{a}$ & $6.90 \mathrm{a}$ & $24.77 \mathrm{a}$ & $6.45 \mathrm{a}$ & $24.97 \mathrm{a}$ & $7.10 \mathrm{a}$ \\
\hline $40 \mathrm{~L} \mathrm{ha}^{-1}$ & $0^{\circ}$ & $24.60 \mathrm{a}$ & $6.98 \mathrm{a}$ & $22.93 \mathrm{a}$ & $5.40 \mathrm{a}$ & $23.99 \mathrm{~b}$ & $6.14 \mathrm{a}$ \\
\hline $40 \mathrm{~L} \mathrm{ha}^{-1}$ & $135^{\circ}$ & $23.81 \mathrm{a}$ & $6.60 \mathrm{a}$ & $22.51 \mathrm{a}$ & $4.93 \mathrm{a}$ & $23.77 \mathrm{~b}$ & $5.39 \mathrm{~b}$ \\
\hline $30 \mathrm{~L} \mathrm{ha}^{-1}$ & $90^{\circ}$ & $25.01 \mathrm{a}$ & $6.28 \mathrm{a}$ & $23.31 \mathrm{a}$ & $5.37 \mathrm{a}$ & $23.79 \mathrm{~b}$ & $6.60 \mathrm{~b}$ \\
\hline Control & --- & $22.86 \mathrm{a}$ & $5.61 \mathrm{a}$ & $24.28 \mathrm{a}$ & $6.12 \mathrm{a}$ & $24.27 \mathrm{~b}$ & $5.74 \mathrm{~b}$ \\
\hline
\end{tabular}

${ }^{1}$ Means followed by distinct letters in the column differ from each other by Student's t-test, 0.05 significance. f: Falker chlorophyll index.

Table 7. Biometric values after the different forms of aerial and ground application of fungicides, aiming at the management of the orange rust of the SP81-3250 sugarcane variety.

\begin{tabular}{llllllll}
\hline \multirow{2}{*}{$\begin{array}{l}\text { Application } \\
\text { rate }^{1}\end{array}$} & $\begin{array}{l}\text { Nozzle } \\
\text { orientation }\end{array}$ & \begin{tabular}{l} 
Stand \\
\cline { 3 - 8 } \\
of tiller m $\mathrm{m}^{-1}$
\end{tabular} & $\begin{array}{l}\text { Biometry } \\
(\mathrm{cm})\end{array}$ & $\begin{array}{l}\text { Stem diameter } \\
(\mathrm{cm})\end{array}$ & $\begin{array}{l}\text { length } \\
\text { 30 L ha }\end{array}$ \\
\hline $30 \mathrm{~L} \mathrm{ha}^{-1}$ & $135^{\circ}$ & $11.10 \mathrm{a}$ & $2.53 \mathrm{a}$ & $209.37 \mathrm{a}$ & $1007.67 \mathrm{a}$ & $77.88 \mathrm{a}$ & 46.88 \\
$40 \mathrm{~L} \mathrm{ha}^{-1}$ & $0^{\circ}$ & $11.07 \mathrm{a}$ & $2.47 \mathrm{a}$ & $200.30 \mathrm{a}$ & $910.00 \mathrm{a}$ & $70.83 \mathrm{a}$ & 39.83 \\
$40 \mathrm{~L} \mathrm{ha}^{-1}$ & $135^{\circ}$ & $9.07 \mathrm{~b}$ & $2.40 \mathrm{~b}$ & $191.43 \mathrm{~b}$ & $906.33 \mathrm{a}$ & $52.37 \mathrm{~b}$ & 21.37 \\
$30 \mathrm{~L} \mathrm{ha}^{-1}$ & $90^{\circ}$ & $9.87 \mathrm{~b}$ & $243 \mathrm{~b}$ & $183.63 \mathrm{~b}$ & $834.67 \mathrm{a}$ & $56.03 \mathrm{~b}$ & 25.03 \\
\hline Control & --- & $8.63 \mathrm{~b}$ & $2.40 \mathrm{~b}$ & $170.40 \mathrm{c}$ & $849.00 \mathrm{a}$ & $50.00 \mathrm{~b}$ & 19.00 \\
\hline
\end{tabular}

${ }^{1}$ Means followed by distinct letters in the column differ from each other by Student's t-test, 0.05 significance. g: Increase in relation to the control plant.

Definitely, crop protection with fungicide was important to increase the yield of at least $19 \mathrm{t}$ ha $^{-1}$ compared to the sugarcane that did not receive any fungicide application.

With the appearance of orange rust in the SP81-3250 variety, doubts about the viability of its cultivation appeared due to their high productivity and high sucrose content, some growers prefer to keep this variety in the properties and, when rust occurs, use specific fungicides. Meanwhile, research institutions are seeking alternatives to replace SP813250 with other more disease-resistant materials. The use of fungicides based on mixtures of the chemical groups strobilurins and triazoles has been shown to be quite effective in the management of sugarcane orange rust, thus making possible to maintain the genetic potency of the crop (MARGAREY, 2008; FERNÁNDES et al., 2013).

Similar results were reported by Rodrigues (2012), when fungicides of the groups Azoxystrobin + Ciproconazole were used. This higher productivity is due to foliar sanity and lower foliar senescence provided by the fungicides used, contributing to higher photosynthetic rates and higher yields.

Systemic fungicides are generally effective in lower coverage conditions when compared to contact fungicides. However, adequate coverage provided by the application technology is necessary even for systemic fungicides, especially when they 
have translaminar movement (BOLLER et al., 2008). According to Staier et al. (2004), the pathogens control depends on the application technology, the climatic conditions and the fungicide effectiveness.

The sugarcane orange rust can be controlled if the correct fungicide is selected, when the application occurs at the beginning of the infection cycle and with a satisfactory coverage of the affected leaves (OLIVEIRA et al., 2011). As the aerial application with $30 \mathrm{~L} \mathrm{ha}^{-1}$ application rate proved to be more efficient than $40 \mathrm{~L} \mathrm{ha}^{-1}$, it is possible to use the lower application volume without reducing disease management and crop productivity. Lower application volumes improved the autonomy and operational capability of aircrafts, reducing costs and covering larger areas (ROMÁN et al., 2009).

\section{CONCLUSIONS}

The aerial application provided better photosynthetic rates compared to ground
ALVES, T. C. et al

application, with better photosynthesis performance in the SP81-3250 sugarcane variety and higher content of chlorophyll $a$ and $b$ in the leaf limbus.

The application rate and the nozzles angulation in the spray bar of the aircraft influenced the gas exchanges as well as the chlorophyll content.

Fungicide applications in the sugarcane crop provided increases of more than $19 \mathrm{t} \mathrm{ha}^{-1}$, depending on the spraying technique employed.

Aerial application with $30 \mathrm{~L} \mathrm{ha}^{-1}$ application rate and orientation of the spray nozzle angle at $0^{\circ}$ of deflection is a viable option to provide safer applications due to the larger droplet size.

\section{ACKNOWLEDGEMENTS}

The authors express their thanks to the Company of Sugar and Alcohol of Minas Gerais (CMAA) - Vale do Tijuco Mill, Produtiva Aeroagrícola and CAPES for supporting this study.

RESUMO: A aplicação de fungicidas em diferentes condições operacionais é uma prática usual para manter o potencial genético em variedades de cana-de-açúcar consideradas susceptíveis à ferrugem laranja, porém os efeitos fisiológicos proporcionados pelos diferentes métodos de aplicação são desconhecidos. O objetivo deste estudo foi avaliar as respostas fotossintéticas (troca gasosa e teor de clorofila) na variedade de cana-de-açúcar SP81-3250, em função de diferentes condições operacionais de aplicação aérea e terrestre de fungicida no controle da ferrugem alaranjada. Duas aplicações de fungicidas dos grupos químicos Estrobilurinas e Triazóis foram realizadas nas unidades experimentais em diferentes tratamentos. Nas aplicações aéreas, foram utilizadas duas taxas de aplicação $\left(30\right.$ e $\left.40 \mathrm{~L} \mathrm{ha}^{-1}\right)$ e três orientações do ângulo dos bicos $\left(0^{\circ}, 90^{\circ}\right.$ e $\left.135^{\circ}\right)$ e na aplicação terrestre $200 \mathrm{~L} \mathrm{ha}^{-1}$ e pontas de pulverização de jato plano com indução de ar (AI11004 -VS). As avaliações de trocas gasosas foram realizadas com analisador de gás IRGA e a quantidade de clorofila $a$ e $b$ com um medidor de clorofila. Os dados foram analisados utilizando o teste t de Student para amostras independentes, com um valor de 0,05 de significancia. A aplicação aérea proporcionou melhores respostas fotossintéticas e os teores de clorofila $a$ e $b$ no membro foliar em comparação com a aplicação terrestre. Foram detectadas diferenças significativas na troca gasosa e no teor de clorofila entre as taxas de aplicação e a angulação dos bicos de pulverização na barra. As aplicações de fungicidas proporcionaram incrementos de mais de $19 \mathrm{t} \mathrm{ha}^{-1}$ em relação ao tratamento controle, dependendo da técnica de pulverização empregada. A aplicação aérea com $30 \mathrm{~L} \mathrm{ha}^{-1}$ e $0^{\circ}$ de deflexão é uma opção viável para proporcionar aplicações mais seguras em função do maior tamanho das gotas. kuehnii.

PALAVRAS-CHAVE: Tecnologia de aplicação. Trocas gasosas foliares. IRGA. Saccharum spp. Puccinia

\section{REFERENCES}

ALVES, G. S.; CUNHA, J. P. A. R. Field data and prediction models of pesticide spray drift on coffee crop. Pesquisa Agropecuária Brasileira, Brasília, v. 49, n. 8, p. 622-629, 2014. https://doi.org/10.1590/S0100204X2014000800006

ARANTES, M. T.; RHEIN, A. F. L.; PINCELLI, R. P.; SILVA, M. A. Respostas fisiológicas de cultivares de cana-de-açúcar a herbicidas seletivos. Bioscience Journal, Uberlândia, v. 29, n. 5, p. 1206-1214, 2013. 
ARAÚJO, K. L.; CANTERI, M. G.; GILIO, T. A. S.; NEUBAUER, R. A.; SANCHES, P. B.; SUMIDA, C. H.; GIGLIOTI, E. A. Resistência genotípica e monitoramento da favorabilidade para ocorrência da ferrugem alaranjada da cana-de-açúcar. Summa Phytopathologica, Botucatu, v. 39, n. 4, p. 271-275, 2013.

ARGENTA, G.; SILVA, P. R. F. da; SANGOI, L. Leaf relative chlorophyll content as an indicator parameter to predict nitrogen fertilization in maize. Ciência Rural, Santa Maria, v. 34, n. 5, p. 13791387, 2004. https://doi.org/10.1590/S0103-84782004000500009

BARBASSO, D.; JORDÃO, H.; MACCHERONI, W.; BOLDINI, J.; BRESSIANI, J.; SANGUINO, A. First report of Puccinia kuehnii, causal agent of orange rust of sugarcane, in Brazil. Plant Disease, Saint Paul, v. 94, n. 9, p. 1170, 2010. https://doi.org/10.1094/PDIS-94-9-1170C

BELLOTI, M. Mecanismo de descarboxilação da fotossintese $\mathbf{C}_{4} \mathbf{e}$ driscriminação isotópica para seleção de genótipos do complex Saccharum spp. tolerantes à seca. 2012. 89 f. Dissertação (Mestre em Ciências) Universidade de São Paulo, Piracicaba, SP.

BIGGS, A. R. Reduction in transpiration and return bloom in apples by two sterol inhibiting fungicides. HortScience, Alexandria, v. 25, n. 11, p. 1403-1405, 1990.

BOLLER, W.; HOFFMANN, L. L.; FORCELINI, C. A.; CASA, R. T. Tecnologia de aplicação de fungicidas Parte II. Revisão Anual de Patologia de Plantas, Passo Fundo, v. 16, p. 85-132, 2008.

BLUM, A. Drought resistance, water-use efficiency, and yield potential - are they compatible, dissonant, or mutually exclusive? Crop and Pasture Science, Clayton South, v. 56, n. 11, p. 1159-1168, 2005. https://doi.org/10.1071/AR05069

CARRIJO, D. R. Efeitos fisiológicos provocados pelo fungicida Fluxapiroxade, isolado e em mistura com a Piraclostrobina, na cultura de soja. 2014. 71 f. Dissertação (Mestrado em Fitotecnia) Universidade de São Paulo Escola Superior de Agricultura "Luiz de Queiroz", Piracicaba, 2014.

CHAPOLA, R. G. Reação de variedades de cana-de-açúcar à ferrugem alaranjada (Puccinia kuehnii). 2013. 77 f. Tese (Doutor em Fitopatologia) Universidade de São Paulo

Escola Superior de Agricultura “Luiz de Queiroz”, Piracicaba, 2013.

CONCENÇO, G.; FERREIRA, E. E.; SILVA, A. A.; FERREIRA, F. A.; VIANA, R. G.; D’ ANTONIO, L.; FIALHO, C. M. T. Uso da água em biótipos de azevém (Lolium multiflorum) em condição de competição. Planta Daninha, Viçosa, v. 25, n. 3, p. 449-455, 2007.

CZACZYK, Z.; KRUGER, G.; HEWITT, A. Droplet size classification of air induction flat fan nozzles. Journal of Plant Protection Research, Poland, v. 52, n. 4, p. 415-420, 2012. https://doi.org/10.2478/v10045012-0068-6

DEMANT, L. A. R; MARINGONI, A. C. Controle da mancha angular do feijoeiro com uso de fungicidas e seu efeito na produção das plantas. Idesia, Arica, v. 30, n. 2, p. 93-100, 2012. https://doi.org/10.4067/S071834292012000200012

FAGAN, E. B.; DOURADO NETO, D.; VIVIAN, R.; FRANCO, R. B.; YEDA, M. P.; MASSIGNAM, L. F.; OLIVEIRA, R. F.; MARTINS, K. V. Efeito da aplicação de piraclostrobina na taxa fotossintética, respiração, atividade da enzima nitrato redutase e produtividade de grãos de soja. Bragantia, Campinas, v. 69, n. 4, p. 771777, 2010. https://doi.org/10.1590/S0006-87052010000400001

FERNÁNDES, M. S.; SEGATO, S. V.; ROCHA, D. R. Produtividade, açúcar e brotação de cana-de-açúcar submetida a fungicidas e maturadores. Nucleus, Ituverava, v. 10, n. 2, p. 323-338, 2013. 
GASCHO, G. J.; SHIH, S. F. Sugar cane. In: TEARE, I. D.; PEET, M. M. (Ed.) Crop-water relations. New York: Wiley-Interscience, 1983. p. 445-479.

GLYNN, N. C.; DIXON, L. J.; CASTLEBURY, L. A.; SZABO, L. J.; COMSTOCK, J. C. PCR assay for the sugarcane rust pathogens Puccinia kuehnii and P.melanocephala and detection of a SNP associated with geographical in P. kuehnii. Plant Pathology, Saint Paul, v. 59, n. 4, p. 703-711, 2010.

https://doi.org/10.1111/j.1365-3059.2010.02299.x

JULIATTI, F. C.; JULIATTI, B. C. M.; BELOTI, I. F.; BORIN, M. S. R.; CRATO, F. F.; JULIATTI, F. C. A moderna proteção de plantas, efeito fisiológico de fungicidas: a arte do controle de doenças em plantas e a sustentabilidade nos sistemas de produção. In: NEFIT-UFLA. (Org.). Avanços na otimização do uso de defensivos agrícolas no manejo fitossanitário. 1. ed. São Carlos: Suprema, 2012. v. 1. p. 126-160.

KÖPPEN, W. Climatología: con un estudio de los climas de la tierra. Cidade do México: Fondo de Cultura Económica, 1948. 479 p.

KÖHLE, H.; GROSSMANN, K.; JABS, T.; GERHARD, M.; KAISER, W.; GLAAB, J.; CONRATH, U.; SEEHAUS, K.; HERMS, S. Physiological effects of the strobilurin fungicide F 500 on plants. In: DEHNE, H. W.; GISI, U.; JUCK, K. H.; RUSSEL, P. E.; LYR, H. (Eds). Modern Fungicides and Antifungal Compounds III. AgroConcept GmbH: Bonn, 2002. p. $61 \square 74$.

LENZ, G.; COSTA, I. F. D.; ARRUÉ, A.; CORADINI, C.; DRESSLER, V. L.; MELLO, P. A. Severidade de doenças e manutenção da área foliar verde em função da aplicação de micronutrientes e fungicidas em trigo. Summa Phytopathologica, Botucatu, v. 37, n. 2, p. 119-124. 2011.

MARGAREY, R. C.; BULL, J. I.; TOMASIN, W. A. Yield loses caused by leaf diseases: 1999 and 2003 selection trial analyses. Proceedings of the Conference of the Australian Society of Sugar Cane Technology, Red Hook, v. 30, p. 303-321, 2008.

MARTINS, A. L. M.; LANDELL, M. G. A. Conceitos e critérios para avaliação experimental em cana-deaçúcar utilizados no programa Cana IAC. Pindorama: Instituto Agronômico, 1995. p. 2-14.

MARTINS, K. V. Caracterização fisiológica e influência das folhas senescentes do estrato inferior na produtividade da cultura de soja. 2011. 77 f. Dissertação (Mestrado em Fitotecnia) -Escola Superior de Agricultura Luiz de Queiroz, Universidade de São Paulo, Piracicaba, 2011.

NASON, M. A.; FARRAR, J.; BARTLETT, D. Strobilurin fungicides induce changes in photosynthetic gas exchange that do not improve water use efficiency of plants grown under conditions of water stress. Pest Management Science, Chichester,v. 63, n. 12, p. 1191-1200, 2007. https://doi.org/10.1002/ps.1443

OLIVEIRA, G. Cadeia respiratória e fosforilação oxidativa - geração de ATP. 2016. Disponível em: <http://www.geocities.com/bioquimicaplicada/resumosatp.thm> Acesso em: 16 dez. 2016.

OLIVEIRA, V. A. B.; OLIVEIRA, G. M.; GIGLIOTI, É. A.; IGARASHI, W. T.; SAAB, O. J. G. A. Desempenho de bicos rotativos e hidráulicos na aplicação aérea de fungicidas em cana-de-açúcar. Revista Brasileira de Tecnologia Aplicada nas Ciências Agrárias, Guarapuava, v. 4. n. 3, p.111-122, 2011.

RAMBO, L.; SILVA, P. R. F.; ARGENTA, G.; SANGOI, L. Parâmetros de plantas para aprimorar o manejo da adubação nitrogenada de cobertura em milho. Ciência Rural, Santa Maria, v. 34, n. 5, p. 1637-1645, 2004. https://doi.org/10.1590/S0103-84782004000500052

RODRIGUES, F. E. Eficácia de Azoxistrobina + Ciproconazol no controle de ferrugem alaranjada em cana-de-açúcar. 2012. 29 f. Trabalho de Conclusão de Curso (Graduação) Tecnologia em Biocombustíveis, Fatec: Faculdade de Tecnologia de Jaboticabal, Jaboticabal, 2012. 
RODRIGUES, M. A. T.; BEGLIOMINI, E.; DOURADO-NETO, D. Efeito fisiológico da piraclostrobina em plantas de feijão. Tropical Plant Pathology, Brasília, v. 34 (supl.), p. 394, 2009.

RODRIGUES, M. A. T. Avaliação do efeito fisiológico do uso de fungicidas na cultura de soja. 2009. $197 \mathrm{f}$. Tese (Doutorado em Ciências) - Escola Superior de Agricultura "Luiz de Queiroz", Universidade de São Paulo, Piracicaba, 2009.

RODRIGUES, M. A. T. Classificação de fungicidas de acordo com o mecanismo de ação proposto pelo FRAC. 2006. 249 f. Dissertação (Mestrado em Agronomia) - Faculdade de Ciências Agronômicas, Universidade Estadual Paulista "Júlio de Mesquita Filho", Botucatu, 2006.

ROMÁN, R. A. A.; CORTEZ, J. W.; DA COSTA FERREIRA, M.; DI OLIVEIRA, J. R. G. Cobertura da cultura da soja pela calda fungicida em função de pontas de pulverização e volumes de aplicação. Scientia Agraria, Curitiba, v. 10, n. 3, p.223-232, maio/jun. 2009. https://doi.org/10.5380/rsa.v10i3.14529

SALES, C. R. G.; RIBEIRO, R. V.; MACHADO, D. F. P.; MACHADO, R. S.; DOVIS, V. L.; LAGÔA, A. M. M. A. Trocas gasosas e balanço de carboidratos em plantas de cana-de-açúcar sob condições de estresses radiculares. Bragantia, Campinas, v. 71, n. 3, p. 319-327, 2012. https://doi.org/10.1590/S000687052012000300001

SHIMAZAKI, K.; DOI, M.; ASSMANN, S. M.; KINISHITA, T. Light regulation of stomatal movement. Annual Review of Plant Biology, Bethesda, v. 58, p. 219-247, 2007.

https://doi.org/10.1146/annurev.arplant.57.032905.105434

SILVA, A. A.; SILVA, J. D. Competição entre plantas daninhas e culturas. In: SILVA, A. A.; SILVA, J. F. (Ed.). Tópicos em manejo de plantas daninhas. Viçosa, MG: Sociedade Brasileira de Ciência do Solo, 2007. p. 17-61.

STAIER, T. N., MARGAREY, R. C.; FINLAYSON, W. A. Meteorological data collection, analysis and sugarcane disease forecasting for orange rust. Proceedings of the Conference of the Australian Society of Sugar Cane Technology, Red Hook, v. 26, p. 25-25, 2004.

TAIZ, L.; ZEIGER, E. Fisiologia vegetal. 5.ed. Porto Alegre: Artmed, 2013. 918 p.

TORRES, L. G.; FERREIRA, E. A.; ROCHA, P. R. R.; FARIA, A. T.; GONÇALVES, V. A.; GALON, L.; SILVA, A. A. Alterações nas características fisiológicas de cultivares de cana-de-açúcar submetida à aplicação de herbicidas. Planta Daninha, Viçosa, v. 30, n. 3, p. 581-587, 2012.

VAN ZYL, J. G. J.; FOURIEA, P. H.; SCHUTTEB, GERHARDUS, C. Spray deposition assessment and benchmarks for control of Alternaria brown spot on mandarin leaves with copper oxychloride. Crop Protection., London, v. 46, n. 4. p. 80-87, 2013.

VILLALBA, J.; HETZ, E. Deriva de productos agroquímicos - Efecto de las condiciones ambientales. In: MAGDALENA, J. C. (Ed.). Tecnología de aplicación de agroquímicos: Argentina: Área de comunicaciones del INTA Alto Valle, 2010. p. 45-54.

ZANDONADI, C. H. S.; CUNHA, J. P. A. R.; ALVES, T. C.; SILVA, S. M. Tank mixture of pesticides for spodoptera frugiperda control in maize with triflumuron. Bioscience Journal, Uberlândia, v. 33, n. 1, p. 31-40, 2017. https://doi.org/10.14393/BJ-v33n1a2017-35733

ZHAO, D.; GLYNN, N. C.; GLAZ, B.; COMSTOCK, J. C.; SOOD, S. G. Orange rust effects on leaf photosynthesis and related characters of sugarcane. Plant Disease, Saint Paul, v. 95, n. 6, p. 640-647, 2011. https://doi.org/10.1094/PDIS-10-10-0762 